\title{
Research into the Application of Linguistic Adaptation Theory in Personal Selling Communication
}

\author{
Danyan Huang \\ International College, Guangdong University of Foreign Studies, Guangzhou, China
}

\begin{abstract}
This is a qualitative study into the interactive communication between the salesperson and the potential customer in the process of personal selling based on Jef Verschueren's linguistic Adaptation Theory. By carefully analyzing the obtained data, which are genuine face-to-face selling cases, the study found that the persuasive utterances made by the salesperson can be classified as the adaptation to one of the three worlds: physical world (including adaptation to stretches of time, to selling environment, to physical appearance and to non-verbal messages), social world (including adaptation to the business tradition of being honest and reliable, to the business rule of valuing time as well as to different ages and sexes), and mental world (including the need for benefit seeking, the need for rapport building, the desire for compliment and the desire for sympathy).
\end{abstract}

Index Terms - personal selling, linguistic adaptation theory, physical world, social world, mental world

\section{INTRODUCTION}

In recent years, with the dramatic growth in people's living standards and hence their strengthened consumption powers, companies are blessed with opportunities. But at the same time, with the increasingly fierce competition in the market, they face challenges as well. To survive in this highly crowded market, sellers are required to promote selling by convincing potential consumers of the superiority of their products or services over their competitors. Personal selling represents an important opportunity for them to achieve that goal. And the most important task of sales representatives is to establish and maintain a reliable relationship with potential or old customers. To pursue this, the choice of appropriate language and selling strategies is of vital significance.

\section{LITERATURE REVIEW}

\section{A. Personal Selling}

Through much of human history, people relied on barter to acquire essential goods and services. Barter is the exchange of a product or service for another product or service. As people's desire to obtain a wider variety of goods grew, barter was replaced by selling, the exchange of products and services for money. Selling, as a critical type of human interaction, is a driving force for a country's economy. Countries depend upon the sales process to survive since their exercise is for the sole purpose of profit-making by meeting the needs of their customers with products or services. Without sales they go bankrupt. Selling is everywhere. Even colleges and universities are "companies" that sell educational products and services. Without consumers (students), they would close the door. When people work, they sell their personal resources (time, energy, effort, skills, and knowledge) to the company they work for. In a word, sales are a vital part of people's lives.

Personal selling was traditionally defined as the process of promoting the exchange of goods or services (Robeson, Mathews \& Stevens, 1977, p.5). It was viewed by others as the process of persuading a potential customer or client to buy a product or service by the seller (Howland, 1978, p.7). In order to achieve the intended selling result, the salesperson needs to acquire a particular set of sales skills and strategies to make the selling communication go smoothly and successfully.

Personal selling is a type of human communication, which can be realized through either verbal communication, that is, the use of words or nonverbal communication including body movement, facial expressions, gestures, eye contact, and so on (Dou Weilin, 2005, p.13). In the process of selling, several selling strategies are also needed for the salesperson to successfully approach the prospective customer, such as news approach, curiosity approach and bonus approach, to keep the customer interested, such as story-telling approach, relaxing atmosphere approach and the use of visual images, and to close the deal, such as the suggestion technique, the assumption technique and the concession technique (Sun, Luhong, 2007, p.56-64).

\section{B. Linguistic Adaptation Theory}

According to Verschueren (1999, p.66-67), contextual correlates of adaptability includes all the ingredients of the 
communicative context with which linguistic choices have to be inter-adaptable, and the range goes from aspects of the physical surrounding to social relationships between speakers and hearers and aspects of the interlocutors' state of mind. It can best be shown in figure 2.1 .

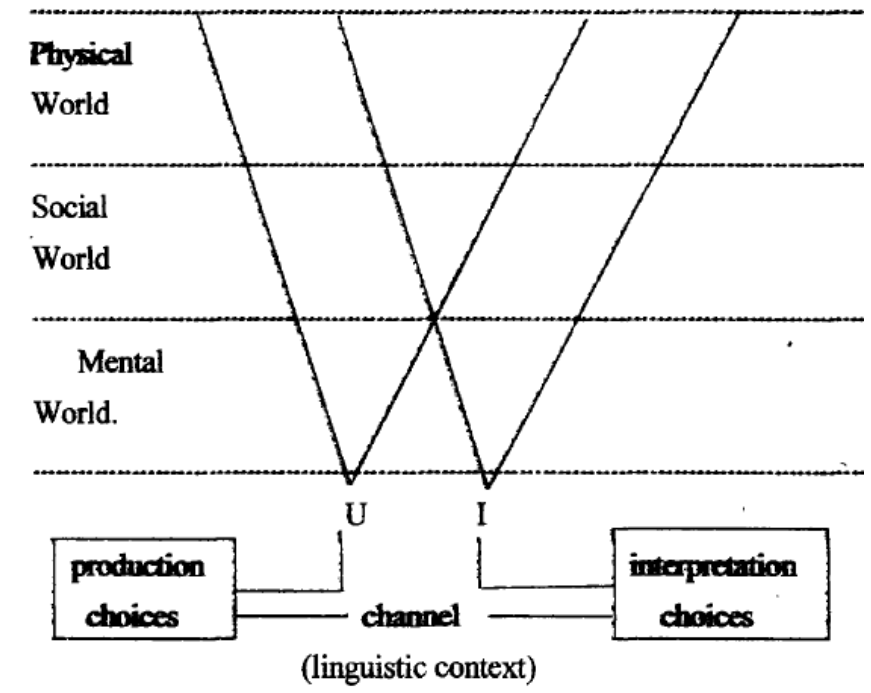

Figure 2.1 Contextual correlates of adaptability (Verschueren, 1999, p.76)

Dr Yu Guodong (2001, p.83) has incorporated persuasive communication into the Adaptation Theory and classified adaptation into passive and active ones, as shown in figure 2.2.

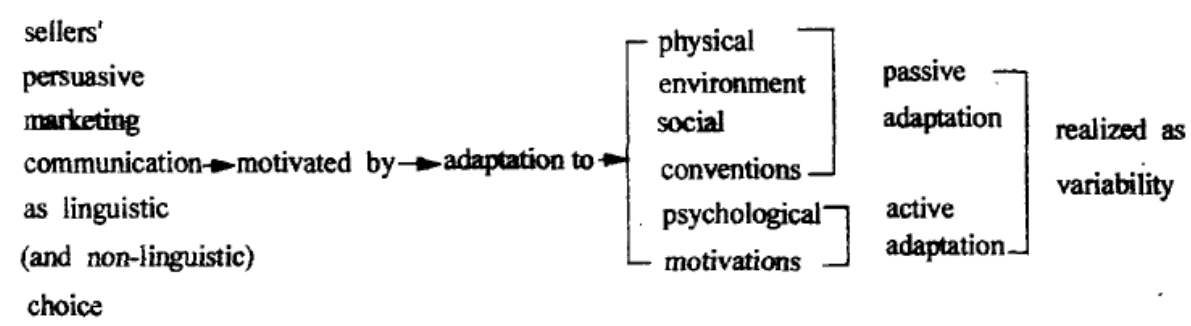

Figure 2.2 the conceptual framework concerning selling process

The world is made up of people with different beliefs and diverse needs and desires to be satisfied. Selecting the appropriate sales strategy for a sales situation and making adjustments during the interaction are crucial to successful selling. This is called adaptive selling, which requires salespeople to adopt customized presentation (a written and/or oral presentation based on a detailed analysis of the customer's needs) in the process of selling. More specifically, salespeople practice adaptive selling when they use different sales presentations for different customers and alter their sales presentation according to the changed sales situation. Adaptive selling emphasizes the importance of satisfying customer needs and building long-term partnerships, and being adaptable increases buyer trust and commitment and results in more ideal sales outcome.

\section{METHODOLOGY}

The chief aim of the research is to investigate how the salesperson uses verbal or non-verbal strategies to achieve his/her sales target in the communication with the target customer so as to adapt to the physical, mental or social world under the guidance of linguistic adaptation theory.

The data are cases of personal selling conversations both in English and Chinese, which have been collected from some websites and such books as Selling Today: A Personal Approach; Personal Selling; How to Perfect Your Selling Skills; Professional Selling; Non-Manipulative Selling; Leaning the Art of Selling Through Watching Movies .

The data are analyzed qualitatively according to Linguistic Adaptation Theory. Categorization is used in the analysis of the data in terms of sub-categories under these three communication worlds outlined above.

\section{CASE AnAlysis}

This part deals with how personal selling adapts to communicative context, which includes the physical world, the social world as well as the mental world of customers. 


\section{A. Persuasive Selling as Adaptation to the Physical World}

\section{Introduction}

According to Verschueren (1999, p.95), temporal deixis and spatial deixis are the most studied and most visible ways of anchoring language choices into a physical world, the relativity of temporal and spatial reference is primarily a function of positioning of language users in the world, and a lot of linguistic choice-making is dependent on properties of this positioning in temporal and spatial terms.

Apart from time and space, the physical world includes bodily postures, gestures, gaze and other aspects of physical appearance or conditions.

\section{Case Analysis}

In the present study, linguistic choices' adaptation to physical world is centered on the adaptation to such aspects as stretches of time, environment of shopping, physical appearance and nonverbal messages. Four cases will be given, followed by detailed analysis according to the categories given.

(1) Daryl Johnson works for Ace Hardware in Oneonta, New York. On June 21, John Roberts enters the store and the following conversation ensues:

Daryl: I notice you're looking at our lawnmowers there. Are you interested in a particular model?

John: Well, I've just bought my first home. I'd always lived in an apartment, and I guess I better buy a lawnmower to cut the grass. What about this one here? It looks pretty good. (Pause, as John looks over the mower) How much is it?

Daryl: That one is priced at $\$ 99.99$. It's on sale, and it's really a good buy.

John: On sale, eh?

Daryl: Yes, but the sale ends tomorrow.

John: Tell me a little bit about the mower.

Daryl: Well, it has solid state ignition, meaning that you'll never have to tune it up. That's really a nice feature. Have you ever tried to tune up your car?

John: No, but I imagine it isn't much fun.

Daryl: It sure isn't.

John: Does it come with a warranty?

Daryl: Yes, it certainly does. Ninety days on parts and labor.

John: Well, I guess I better buy it if it's on sale.

Daryl: Fine, I'll write up a ticket. (Manning, G. L. and Reece, B. L., 1987, p.32-33)

While talking with customers, salespeople attempt to make them "act now" by telling them that there is a "limited time offer". They are relying on the principle of scarcity, and by limiting the customers' time they hope to make them quickly decide to purchase their products. In case (1), the customer called John wants to buy a lawnmower and thus enters a store owned by Daryl, the salesperson. Apparently, at the initial stage of approaching customers, Daryl successfully attracts John's interest by saying that the particular lawnmower which John is asking for is on sale and that the sale will end next day, indicating that if John don't act this time he will lose a good opportunity to buy a high-quality product at a low price. Then, during the stage of presentation, Daryl talks about the product's features and advantages with such words as "solid state ignition", which intrigues the customer further, hence the use of product-benefit method, a popular persuasion technique in personal selling. Another adaptation to time lies in the ninety-day warranty offered by the salesperson, which is also a good strategy to close the deal, more specifically, the strategy by means of ethos or source credibility in that the salesperson offers a guarantee to the customer enabling his to gain trust from the latter. Thus saying, in terms of the persuasion strategy used, an appeal to both the rational and emotional needs of the customer is employed by the salesperson.

(2) Bill is a Proter \& Gamble salesperson who plans to call on Ms. Hansen, a buyer for his largest independent grocery store. He enters the grocery store, check his present merchandise, and quickly develop a suggested order. As Ms. Hansen walks down the aisle toward him, she appears to be in her normal grumpy mood. After the initial greeting and handshake, the conversation continues:

Salesperson: Your sales are really up! I've checked your stock in the warehouse and on the shelf. This is what it looks like you need.

Buyer: OK, that looks good. Go ahead and ship it.

Salesperson: Thank you. Say, Ms. Hansen, you've said before that the shortage of shelf space prevents you from stocking our family-size Tide- though you admit you may be losing some sales as a result. If we could determine how much volume you're missing, I think you'd be willing to make space for it, wouldn't you?

Buyer: Yes, but I don't see how that can be done.

Salesperson: Well, I'd like to suggest a test $-\mathrm{a}$ weekend display of all four sizes of Tide.

Buyer: What do you mean?

Salesperson: My thought was to run all sizes at regular shelf price without any ad support. This would give us a pure test. Six cases of each size should let us compare sales of the various sizes and see what you're missing by regularly stocking only the smaller sizes. I think the additional sales and profits you'll get on the family size will convince you to start stocking it regularly. What do you think?

Buyer: Well, maybe. 
Salesperson: May I enter the six cases of family-size Tide in the order book now? (http://www.coursehero.com/)

The selling environment is an important factor that needs to be taken into account, especially when the salesperson has to visit the prospect in the latter's home or office. A person's living place can to some degree reflect that person's preferences and interests, and even his/her personality. When visiting the prospect, the salesperson needs to take a close look at the selling environment and work out a good way to approach the prospect. In case (2), the salesperson, Bill, approaches an old customer, Ms. Hansen, the owner of a large grocery store, by saying that "your sales are really up!", an appeal to the emotional need for compliment. Then he said he has checked Ms. Hansen's stock in the warehouse and on the shelf, apparently an adaptation to the selling environment. Base on this adaptation, he proposed some plans to increase the customer's sales, an appeal to the rational need. Through that way, he succeeds in persuading the customer to continue to buy his products. A customer is liable to be convinced by a fully-prepared salesperson who takes his/her condition into serious condition.

(3) A salesperson, responsible for selling sales training programs, has an appointment with a bank president to talk over the possibility of enrolling the bank's tellers and trust people in a sales training session. On entering the president's office, the sales representative notices the decorations on the walls: a picture of the new bank on which construction is to begin shortly, several graphs of interest rates and money supply from the Federal Reserve Bank, and a diploma from the American Institute of Banking. The salesperson is motioned to sit down in a comfortable but functional chair directly across from the president's desk, on which there appears nothing but a blotter. Before taking a seat, the salesperson extends his hand warmly.

Salesperson: Good morning, Ted. How are you today? Sure is nice weather we're having.

President: (a little hesitant, at first, to extend his hand) Yes, it certainly is. I have about five minutes to talk with you. I'm running on a tight schedule today. Now tell me something about your program. (Sits down to listen expressionlessly)

Salesperson: Well, let me tell you how I got around to calling you. I was talking to Bob Johnson over at Century Realty. We just completed a sales training program over there for his real estate agents. Do you know Bob?

President: Yes, I do. He does business here at the bank.

Salesperson: A great guy. He and I play golf all the time. He's a scratch golfer, but every once in a while I take some money from him. Do you play golf?

President: No, I don't. (Looking at his watch)

Salesperson: Well, anyway, out at the course - make that clubhouse-Bob and I got to talking and he mentioned that you were getting interested in marketing your bank more seriously. I'd just like to say that's a great idea. More bank presidents should think like you.

President: Yes, we hope to increase our competitive market share vis-à-vis the other banks in town by at least 5 percent. We feel that's realistic, given the experience of other banks which have become marketing oriented. Now, tell me something about what your program can do for us at First Federal.

Salesperson: We can do some great things for you. After completing our training program, I can guarantee your tellers and trust people will be real go-getters, the kind of salespeople any company would be proud to have.

President: I'm sure. What sorts of sales skills does your program cover?

Salesperson: Why, we teach every selling skill the successful salesperson needs to know. Bob Johnson really found our program helpful to his people. Business doubled shortly thereafter, and he credited it to us.

President: Doubled?

Salesperson: At least. No question about it.

President: I wonder if you could be a little more specific about exactly what you propose for training our people?

Salesperson: We use a number of different methods: role playing, lectures, transparencies, and slides. We've got the best program around. Just listen to some of the companies we've worked with...

President: Excuse me for interrupting, but I see that our time is up and I have a meeting coming up shortly. Why don't you leave some information listing the details of your program.

Salesperson: Fine. Here we are. Listen, maybe we can make an appointment to meet out at the club for lunch.

President: I usually go over to the YMCA to run at noontime.

Salesperson: That's great! I bet you're in great shape. Well, I guess I can get in touch with you for another appointment. (Mondy, W. R., Premeaux, R. S. and Young, R. J., 1989, p.56-58)

Nonverbal messages are regarded as a good indication of a person's mental state. Their interpretation varies from one culture to another. So, it is important for the salesperson to understand the meanings of some common ones when doing business in a particular culture. Case (3) is an example showing the salesperson's successful adaptation to nonverbal messages conveyed by the customer. In this case, the customer sends out such nonverbal messages as "he is not so willing to see the salesperson" and "he is busy" by such gestures as "a little hesitant", "sits down to listen expressionlessly", and "looking at his watch". Sensing this, the salesperson constantly changes his persuasion strategies from referral approach (one in which a third party is introduced to build rapport with the salesperson) to benefit approach ("doubled business"), thus successfully gains the customer's cooperation.

(4) Terry Trine, a well-dressed woman in her thirties, has just walked into the showroom of the American Co., a volume retail appliance dealer. She is greeted by a salesperson: 
Salesperson: Good morning, ma'am. Is there something I can help you with?

Trine: Yes, most certainly. I'm interested in a microwave - a good one!

Salesperson: That's the only kind we sell!

Trine: Yes, I'm sure.

Salesperson: I suggest this model here. It's only $\$ 199.99$ this week, and it'll get the job done. If you get home later from shopping and the kids and old man are crying for their dinner, you can poop it in the microwave here and have it ready in a second. Remember now, this model goes off sale this week, and the price goes back up to \$249.95.

Trine: Don't you have any digital models? I understand you're able to program recipes into the machine that way and not have to worry about whether you're cooking the right amount of time.

Salesperson: You can, but those models cost a lot more, and you really aren't getting that much for your money. Besides, just think what your husband would say if he knew you wanted to spend over $\$ 500$ on a microwave. I suggest you bring him by for a demonstration.

Trine: I believe I'm capable of making the decision myself. Does this model you suggest have a temperature probe? I make quite a few dishes, such as quiche, where that's critical.

Salesperson: No, it doesn't, but you can pretty well judge by heating for a while and tasting the food.

Trine: I like to be surer than that. What about a revolving tray, so that the food heats evenly all over? I understand that otherwise part of the food may be hot while another part can be lukewarm or cold.

Salesperson: That's true, but again, you pay for that feature. If you get all the features you've asked about, you might spend as much as $\$ 700$. I don’t think you really want to spend that much.

Trine: It depends on whether I get what I want.

Salesperson: Tell you what, let's take a look at this model here which has the features you've mentioned, but I think you're going to spend a lot more money and...(Manning, G. L. and Reece, B. L., 1987, p.36-37)

Both the physical appearance of the salesperson and the prospect need to be considered. Normally, salespeople are required to wear suits and ties in order to show his/her own professionalism and respect for the customer. And as salespeople, they also need to notice the physical appearance of their customers, which will help them to recognize customers' profession, personality and style.

Case (4) is an example of the failure to adapt to the customer's physical appearance. In this case, the customer called Terry Trine, a well-dressed woman in her thirties, wants to buy a microwave, "a good one" in her own words. The salesperson greets with her and then introduces a model which is on sale that week. When Ms. Trine asks for some digital models, instead of introducing one immediately, the salesperson says that digital ones will cost a lot more. And then when Ms. Trine asks whether the recommended model has a specific feature that she desires, again the salesperson says the models with such a feature will cost more. Actually, through the customer's physical appearance ("well-dressed") and her reactions during the presentation stage of selling, we can infer that she can afford a good model of microwave and will be willing to spend a lot of time on the one she really likes. But the salesperson doesn't realize that and as a result fails to sell his/her product.

\section{B. Persuasive Selling as Adaptation to the Social World}

This part focuses on the discussion of linguistic adaptation to the social world, which can be referred to as adaptation to human's subjective world.

\section{Introduction}

There is no standardized limit to the range of social factors that linguistic choices are adaptable to. Most of them have to do with properties of social settings or institutions. Social settings and institutions imply certain principles and rules according to which certain types of linguistics acts are regarded desirable. Other social dimensions of variability with which linguistic choice-making is interadaptable include social class, ethnicity and race nationality, linguistic group, religion, age, worshipping, level of education, profession, kinship, gender, sexual preference, and so on (Verschueren, 1999).

\section{Analysis}

In the present study, linguistic adaptation to the social world will be mainly targeted on such aspects as the adaptation to the business tradition of being honest and reliable (source credibility), the business rule of valuing time, sexes and ages. In the following, three cases will be presented and analyzed in order to illustrate the importance of adaptation to the social world in personal selling.

(5) The new sales representative of a pharmaceutical manufacturing company walks into the pharmacy department for the first time.

Rep: My name is Frank Baker, from W. Smith Laboratories.

Buyer: No use calling on me. I will never again buy from your company?

Rep: I'm shocked to hear that! Could it have been something the company did or the recent rep, whom I know to have been a fine person? I would personally appreciate your kindness by telling me how we could get back into your good graces.

Buyer: I returned about $\$ 30$ worth of your merchandise about three months ago, and the office never credited my account and continually billed me. I called the office, and some woman said, "That medicine was outdated and we don't give credit for such items." I told her I gave it to the salesman and he said he would take it back. She said, "That rep is 
no longer with us and there is nothing I can do," and hung up!

Rep: If I were you, I would feel exactly as you do. You are 100 percent justified in your attitude. Our company was not in error, but the rep failed by not picking it up before it became outdated! The office employee was thoughtless in her discourtesy to you, a good customer, on the phone. Your store routinely sells our products A and B and you make a reasonable profit on these items. If my sales manager approves (and I'm sure she will), I would be pleased to replace the $\$ 30$ you did not get credit for with the products you now sell and will deliver them personally tomorrow if you will be in about 2 p.m.

Buyer: Well, that should do it. I'll see you tomorrow when you come to check our stock for any "outdated" merchandise.

Rep: Thank you for understanding. I feel much better now. (Weymes Pat, 1990, p.41-42)

Being honest and reliable is the most treasured ethic requirement of business in any society. It is an important ingredient of source credibility. Once the credibility of a company or a salesperson is ruined, it is hard to get recovered, since customers will choose to buy from other companies rather than make a second purchase from somebody who has disappointed him/her. Thus, salespeople should serve customers faithfully, engage in trade honestly, and be trustworthy. The salesperson should be honest with every single customer, abide by the law, guarantee the quality of the product, and make a deal legally.

Case (5) is a good example of the salesperson's adaptation to the business tradition of being honest and reliable, a very important aspect of the social world in personal selling. In this case, the sales representative is greeted by the prospective customer's anger, which is indicated by his statement "No use calling on me. I will never again buy from your company." Then by asking the reason the salesperson discovers that the buyer had an unhappy experience in dealing with the previous salesperson and the receptionist in his company, which appears to be a big challenge to the company's credibility. However, the salesperson succeeds in persuading the customer to trust his company again by firstly showing his sympathy to the latter's bad experience ("If I were you, I would feel exactly as you do. You are 100 percent justified in your attitude."), a persuasion strategy by means of pathos, and then pointing out the fact that it is the former salesperson as well as the impolite receptionist instead of the company to blame, and finally giving a proper recommendation to solve the problem.

(6) The salesperson calls on a purchasing manager to elicit an order for some electric cars (like a golf cart) to be used at a plant for transportation around the buildings and grounds. Here is the conversation:

Salesperson: Hello, Mr. Pride, my name is Karen Nordstrom and I'd like to talk with you about how to save your company executives' time. By the way, thanks for taking the time to talk with me.

Buyer: What's on your mind?

Salesperson: As a busy executive, you know time is a valuable commodity. Nearly everyone would like to have a few extra minutes each day and that is the business I'm in, selling time. While I can't actually sell you time, I do have a product that is the next best thing... a Dyno Electric Cart - a real time-saver for your executives.

Buyer: Yeah, well, everyone would like to have extra time. However, I don't think we need any golf carts.

Salesperson: Dyno Electric Cart is more than a golf cart. It is an electric car designed for use in industrial plants. It has been engineered to give comfortable, rapid transportation in warehouses, plants, and across open areas.

Buyer: They probably cost too much for us to use.

Salesperson: First of all, they only cost $\$ 2,200$ each. With a five-year normal life, that is only $\$ 400$ per year plus a few cents electricity and a few dollars for maintenance. Under normal use and care, these carts only require about $\$ 100$ of service in their five-year life. Thus, for about $\$ 50$ a month, you can save key people a lot of time.

Buyer: It would be nice to save time, but I don't think management would go for the idea.

Salesperson: This is exactly why I am here. Your executives will appreciate what you have done for them. You will look good in their eyes if you give them an opportunity to look at a product that will save time and energy. Saving time is only part of our story. Dyno carts also save energy and thus keep you sharper toward the end of the day. Would you want a demonstration today or Tuesday?

Buyer: How long would your demonstration take?

Salesperson: I only need one hour. When would it be convenient for me to bring the cart in for your executives to try out?

Buyer: There really isn't any good time.

Salesperson: That's true. Therefore, the sooner we get to show you a Dyno cart, the sooner your management group can see its benefits. How about next Tuesday? I could be here at 8:00 and we could go over this item just before your weekly management group meeting. I know you usually have a meeting Tuesdays at 9:00 because I tried to call on you a few weeks ago and your secretary told me you were in the weekly management meeting.

Buyer: Well, we could do it then.

Salesperson: Fine, I'll be here. Your executives will really be happy! (Kurtz, L. D. and Dodge, R. H., 199, p.75-76)

Time is money, especially in the business world. No businessperson can afford to waste any time, and no single customer wants to lose his/her valuable time to unnecessary events or things, since everyone has limited time to spend. Case (6) has illustrated the importance of adapting to the business rule of valuing time. In this case, the salesperson approaches the buyer by using a benefit technique-"I'd like to talk with you about how to save your company 
executives' time", which is a persuasion strategy by means of pathos. He then proceeds with the emphasis on the value of time by saying that "time is a valuable commodity", and that "I have a product that is a real time-saver for your executives," through which his purpose for this call is presented and at the same time the customer's interest is aroused. And during the presentation stage of selling, the salesperson repeatedly attaches importance to the unique advantage of his product - it can save time, thus convinces the prospect to get the management's approval as soon as possible.

(7) Julie Duvall, a senior at the University of Missouri, has just entered Seifert's, a women's clothing store in Columbia, Missouri.

Salesperson: Good morning. Is there anything I can help you with?

Julie: I'm graduating this spring and I need a new outfit for job interviews.

Salesperson: That's great. Did you have something specific in mind?

Julie: A nice skirt, maybe. I doubt if a pants suit will impress interviewers.

Salesperson: I suppose not. Were you thinking about a wool skirt?

Julie: Probably. Do you have any in navy blue?

Salesperson: Yes, over here. (Picking out one skirt to show) How about this one? It looks like it'll do.

Julie: (Looking at the skirt and examining it) I think I'd like to try it on. I'm not sure, but maybe I'll know when I do. Salesperson: Fine.

Julie: (Looking in mirror) I believe it needs to be a little shorter.

Salesperson: It sure looks good on you, and shortening it is no problem. We can have it ready by next week at the latest.

Julie: That sounds good, but let me look at some other skirts. (Looking through the rack and pulling out four more) These look good, too. (Pausing and thinking) I believe I'll try this one on.

Salesperson: Okay.

Julie: (Looking at herself in the mirror) This looks good too. But, then, so did the first one. And these others are attractive. I don't know which to choose.

Salesperson: You're right. All five are attractive.

Julie: (After looking at the skirts and pondering for a while) This should suffice.

Salesperson: Fine. Will there be anything else?

Julie: No, that's all.

Salesperson: All right. It'll take just a minute to wrap it up. (Alessandra, T., Wexler P. and Barrera, R., 1992, p.73-74)

Males and females always want to get different things from the same product apart from its basic functions. Take clothes as an example. Females attach more importance to the clothes' being beautiful and dignified, elegant and in good taste, while males lay more stress on the quality of the clothes, and high grade of the clothes which possess the value not included in the material object such as to satisfy their desire for power and status. As a result, salespeople should adapt to these different tastes or preferences accordingly.

Case (7) is a good example to show how important for a salesperson to adapt to different desires or needs of people of different genders. It is a natural instinct for women, especially a young one, to like to look attractive. In this case, when the customer, a young lady, asks the salesperson for advice of buying a proper outfit for job interviews, the salesperson recommends a wool suit, since she knows from her selling experience that most girls would look more charming in skirt than pants suit. It seems that her recommendation has really worked and the customer seems to admire herself in the mirror while wearing a skirt. Then the salesperson shows her patience when the customer wants to try other styles on, since she is keenly aware that girls tend to enjoy the process of purchasing and like to compare various types before making a final decision. The result is a successful sale and a satisfied customer who may recommend her friends to come and buy.

\section{Persuasive Selling as Adaptation to the Mental World}

The previous two parts discussed linguistic adaptation to physical world (objective world) and linguistic adaptation to social world (subjective world) respectively. In the competitive market, sellers feel it more and more important to grasp consumers' psychology because their psychological change dominates their action of buying. This part will discuss linguistic adaptation to customers' mental world.

\section{Introduction}

In personal selling, to identify the customer's needs or desires, more specifically, his/her buying motives, is essential for the realization of the salesperson's selling goal.

According to Maslow's Hierarchy of Needs, there are mainly five categories of human needs, which, from the lowest level to the highest level, are physiological needs, safety needs, belongingness and love needs, esteem needs as well as self-actualization needs, and only after lower-level needs have been satisfied can people pursue higher ones (2002). However, one can never exhaust the list of needs that motivate customers to buy goods and services, since needs and desires are constantly changing in response to an individual's physical condition, environment, interactions with others, and experiences.

\section{Analysis}

In the present study, salespeople's linguistic adaptation to customers' mental world can be approximately divided into: 
the adaptation to the need for benefit seeking, the need for rapport developing, the desire for compliment and the desire for sympathy. In the following, another four cases will be given and discussed aiming at the revelation of the importance of adapting to the customer's various needs and desires in selling process.

(8) Denise Mason was one of the salespeople in the gourmet food department of a major department store. A well-dressed young man entered and, after being greeted by Denise, asked if she could suggest an interesting gift. The conversation went as follows:

Denise: We have imported biscuits, jams, condiments, and candies.

Customer: I am looking for a gift for my father-in-law. He's French and I thought he'd be pleased with some kind of gourmet delicacy.

Denise: We have a wide selection of imported foods and specialties from all over the world. You can surely find something interesting.

Customer: Perhaps I ought to buy something more personal?

Denise: How long has your father-in-law been in this country?

Customer: About 10 years.

Denise: An assortment of preserved fruits from France will make a great gift. It would be a reminder of his country.

Customer: Okay, make up an assortment for me. Please wrap them for a gift. (Sun Luhong, 2007, p.101)

Everyone wants to get something in return for his time or money. In selling, salespeople tend to use benefit statement to draw prospects' attention and arouse their interest in the product or service they sell. More specifically, the customer wants such benefits as good quality and low price of goods and services if he/she is a consumer, and maximized profits if he/she is a producer or reseller.

Case (8) is an example displaying the salesperson's adaptation to the prospect's desire for benefit-seeking, an important aspect of the mental world in personal selling. In this case, the customer is looking for a gift for his father-in-law at a gourmet food department. After knowing that the customer wants to buy something more personal, the salesperson asks a specific question to decide the best suitable gift for this old man, and then he recommends an assortment of preserved fruits from France, which, in his words, could "be a reminder of his country", since this old man has been in this country for 10 years. Thus by adapting to the specific need of the customer-his desire to make the recipient of his gift happy and to the particular need of the recipient - his nostalgia, the salesperson makes the sale.

(9) Here is a part of a dialogue between a furniture manufacturer's representative and a customer.

Salesperson: Carl Hamilton at Simmons' Modern Furniture suggested that I visit with you about our new line of compact furniture designed for today's smaller homes. He feels this line might complement the furniture you currently feature.

Customer: Yes, Carl called me yesterday and mentioned your name and company.

Salesperson: Before showing you our product line, I would like to ask you some questions about your current product mix. First, what do you currently carry in the area of bedroom furniture? (Kurtz, L. D. and Dodge, R. H., 199, p.81)

Rapport in selling is a close, harmonious relationship founded on mutual trust. Ultimately the goal of every salesperson should be to establish rapport with each customer. Often the salespeople can accomplish this with some friendly conversation early in the call. The talk about current news, hobbies, mutual friends, and the like that usually breaks the ice for the actual presentation is often referred to as small talk, which is useful for one to develop rapport with customers.

Case (9) is an example to show the importance of adaptation to the customer's need for rapport-developing. In this case, the salesperson approaches the customer by saying that it is the latter's acquaintance called Carl Hamilton who suggested him to have this visit. In this way, the salesperson successfully builds a rapport with the prospect, which makes it much easier for him to carry on the presentation of his product.

(10) Mr. Li owns a grocery store. He is a stubborn person and hates to be pushed into buy anything. This day, Jim, a salesman for a soap factory came to Mr. Li's store. Before Jim had a chance to talk at all, Mr. Li shouted: "Why you come here? I don't need anything!"

Instead of being intimidated, Jim said with a big smile on her face: "Sir, do you know why I am here today?"

"No need to guess, you come here to push me to buy your stupid products!" Mr. Li replied rudely.

Hearing this, Jim burst into laughter, and said: "Sir, I have to say that you have made a wrong guess. My purpose today is not to sell you something but to ask you to sell me something."

"What do you mean?" Mr. Li was shocked a little.

"I heard that you are an excellent seller in this area and the soaps in your store are a best seller. I'm here to beg for your selling secret", Jim replied.

Then Mr. Li happily talked about his selling policies. And at the end of the conversation, he made an order of 30 boxes of soaps from Jim. (Alessandra, T., Wexler P. and Barrera, R., 1992, p. 92)

Everyone likes to receive compliment. Compliment is especially effective for a salesperson when he/she is engaged in a conversation with a prospect who regarded himself/herself as an expert, who has a big ego, or who is in a bad mood. By complimenting them, they will listen and respond favorably to his/her presentation. The prospect with low self-esteem or the one who has trouble making decisions also will respond favorably to a compliment. 
Case (10) is a good example, which shows the salesperson's adaptation to the customer's desire for compliment. When confronted with the customer's unwillingness to give him a chance to make a conversation, Jim, the salesperson asks the prospect, "Sir, do you know why I am here today?" And then he attempts to gain the prospect's interest by stating that I come here to "ask you to sell me something" instead of me selling you something. He continues to explain that he has heard that the prospect is an excellent seller in this area. Here a compliment approach is adapted in order to adapt to the customer's mental world. Actually, the salesperson doesn't compliment the prospect's excellence in selling directly. Instead, he begs for the prospect's experience, which makes the latter proud of himself and leaves a good impression on his mind. In this way, the salesperson has the prospect let down his guard and finally achieves his selling purpose.

(11) Here is a part of a dialogue between the industrial equipment salesperson and a prospect.

Prospect: I have been using your portable generators and do not want to use them anymore.

Salesperson: Why?

Prospect: Well, the fuses kept blowing out and causing delays in completing this project! So get out of here and take your worthless generators with you.

Salesperson: [With a smile] Thank you for telling me. Say, you and our company's design engineers have a lot in common.

Prospect: Oh yeah? I'll bet! [Sarcastically.]

Salesperson: Suppose you were chief engineer in charge of manufacturing our generators. What would you do if valued customers - like yourself-said your generators had problems?

Prospect: I'd throw them in the trash.

Salesperson: Come on, what would you really do? [With a smile.]

Prospect: Well, I would fix it.

Salesperson: That's why I said you and our design engineers have a lot in common. They acted on your suggestion — don't you think? (Sun Luhong, 2007, p.123)

People who have suffered tend to need consolation or sympathy from others. In the business world, former bad experiences will cause a buyer to be more alert for the second time. Therefore, when meeting with such kind of prospects, salespeople have to firstly let down their guards by showing understanding and sympathy, and only then can they have a chance to make proper recommendations.

Case (11) is an example showing the salesperson's adaptation to the customer's desire for sympathy. In this case, the salesperson is confronted with the customer's complaint about the former product that he/she has bought from the salesperson. The salesperson then tries to solve the problem by firstly showing his/her sympathy with the buyer's suffering regardless of the latter's rudeness. Then he uses a strategy called reverse psychology by saying that "you and our company's design engineers have a lot in common." Then, the prospect is listening, giving the salesperson time to explain the product's new features and to make an offer to repair the old units. Thus, the salesperson is ready to sell more products, if possible.

\section{Summary}

This section discussed the seller's linguistic and non-linguistic adaptation to the physical, social and mental world in the interactive communication with the potential customer. It showed that successful adaptation to either one of the three worlds is of critical significance for the smooth flow of the conversation and thus the final success in winning the customer's trust and getting an order.

\section{CONCLUSION}

Through the classification of the data and by using the Linguistic Adaptation Theory as the starting-point, this study found that the salesperson's choice of persuasive language and strategies is motivated by adaptation.

First, the persuasive personal selling is made through adaptation to the physical world, which includes the salesperson's linguistic and non-linguistic adaptation to stretches of time, to the selling environment, to/of physical appearance, and to non-verbal messages.

Second, the communication of persuasive personal selling adapts to the social world, including the salesperson's linguistic adaptation to the business tradition of being honest and reliable, the business rule of valuing time as well as different ages and sexes.

Third, the persuasive personal selling is motivated by adaptation to the mental world. It includes salespeople's linguistic adaptation to customers' need for benefit seeking, need for rapport developing, desire for compliment, and desire for sympathy.

It is, however, worth noting that the subdivision of these three worlds is based on the data collected by the present author, and thus it is not exhausted. Also, to separate the discussion of these three worlds is only for the sake of convenience in the present research, and it is likely that adaptation to more than one world exists in a single case.

\section{REFERENCES}

[1] Abraham H. Maslow. (2002). The Psychology of Science: A Reconnaissance. United States of America: Ann Kaplan. 
[2] Alessandra Tony \& Wexler Phil \&Barrera Rick. (1992). Non-Manipulative Selling. New York: Simon \& Schuster, Inc.

[3] Dou, Weilin. (2005). Cross-cultural Business Communications. Beijing: Higher Education Press.

[4] Howland, R.H. (1978). Self-review in Principles of Salesmanship. Homewood: Richard D. Irwin, Inc.

[5] http://www.coursehero.com/ (2009)

[6] Kurtz, L. D. \& Dodge, R. H. (1991). Professional Selling. RICHARD D. IRWIN, INC.

[7] Manning, G. L. \& Reece, B. L. (1987). Selling Today: A Personal Approach. Wm. C. Brown Publishers, Dubuque, Iowa.

[8] Mondy, W. R. \& Premeaux, R. S. \& Young, R. J. (1989). Personal Selling. Massachusetts: Allyn and Bacon.

[9] Robeson, J.F. \& Mathews, H.L. \& Stevens, C.G. (1977). Selling. Homewood: Richard D. Irwin, Inc.

[10] Sun Luhong. (2007). Learning to Sell by Watching Movies. Beijing: China Renmin University Press.

[11] Verschueren J. (1999). Understanding Pragmatics, Foreign Language Teaching and Research Press.

[12] Weymes Pat. (1990). How to Perfect Your Selling Skills. Kogan Page Ltd, 120 Pentonville Rd. London.

[13] Yu, Guodong. (2001). Pragmatic Research into English-Chinese Code Switching. Shanxi: Shanxi Education Press.

Danyan Huang, born in Shaodong, Hunan Province on December $2^{\text {nd }}$ in 1984, earned the bachelor degree in the English language in Southwest Jiaotong University in Chengdu, China in 2008 and the master degree in foreign linguistics and applied linguistics in Guangdong University of Foreign Studies in Guangzhou, China in 2010.

Since the September of 2010, she has been working as a teacher of English in the International College of Guangdong University of Foreign Studies, located in Baiyun District of Guangzhou, China. Now as a lecturer, she is mainly responsible for the instruction of such courses as Grammar, Comprehensive English, Listening and Writing during the academic year and IELTS Reading in the summer training program. Her previous publications include Internationalization of Chinese Higher Education, published in Higher Education Studies, Canadian Center of Science and Education, 2013 (as the second writer), A Study on Intercultural Business Negotiation-Based on a Case, published in Overseas English, Hefei of Anhui, China: Anhui Science and Technology Press, 2013, and A Study on the Teaching Model of Business English Writing, published in Journal of Language and Literature Studies, Hohhot of the Inner Mongolia Autonomous Region, China: Adult Education College of Inner Mongolia Normal University, 2013, A Study on the Application of Task-based Language Teaching Method in a Comprehensive English Class in China, published in Journal of Language Teaching and Research, Academy Publication, 2016. Her previous research interests lay in pragmatics and business English while currently she is keen on second language classroom research mainly due to her teaching experience in this field. 